\title{
Implementation of Problem Based Learning Models to Improve the Attitude of Environmental Care of Grade V Elementary School
}

\author{
$1^{\text {st }}$ Dewi Puji Rahayu* \\ Departmen of Pre-School and \\ Elementary School Education \\ Universitas Musamus \\ Merauke, Indonesia \\ rahayu@unmus.ac.id
}

\author{
$2^{\text {st }}$ Umar Yampap \\ Departmen of Pre-School and \\ Elementary School Education \\ Universitas Musamus \\ Merauke, Indonesia \\ yampap_fkip@unmus.ac.id
}

\author{
$3^{\text {st }}$ Agus Kichi Hermansyah \\ Departmen of Pre-School and \\ Elementary School Education \\ Universitas Musamus \\ Merauke, Indonesia \\ aguskichi@unmus.ac.id
}

\begin{abstract}
This study aims to improve the attitude of environmental care by using the problem based learning model. This research is a classroom action research study subjects of class V students. Data collection techniques using observation, interviews and documentation. The attitude of environmental care can improve through several processes, namely 1) the implementation of learning under the syntax of the Problem Based Learning model, 2) the attitude of environmental care of class $V$ students has increased after applying the Problem Based Learning model. The increase in the attitude of environmental care can be seen from the results of observations that show that the category of environmental attitudes of students is in the good category of $77.63 \%$ is in the seventh indicator able to classify organic and inorganic waste, while the very good category is in the fourth indicator namely dare to reprimand friends who glittering with an assessment of $85.65 \%$ from cycle I to cycle II.
\end{abstract} care

Keywords: problem based learning, attitude of environmental

\section{INTRODUCTION}

The aim of the school is not only to memorize theories or just to get satisfactory grades / learning outcomes, but to theorize according to the reality around students and produce graduates who have a caring attitude towards the environment. A place where the living creature live is environment [1]. Education must build students' thinking that is dynamic, skilled in finding solutions to a problem that exists in the real world and is open in line with the reality around students.

The problem found by researchers at the time of observation is the lack of caring attitude towards students. This is shown by several dimensions of problems including the low awareness of students to dispose of trash in its place. This situation occurs in class $\mathrm{V}$ where the class looks like trash in the desk drawer. Like the amount of plastic waste, shredded paper, pencil sharpener, and rotting food for forgetting to throw away, the flowerpot that should be a container for plants becomes polluted with garbage, and the plants in the school are not watered. Lessons that encourage students to cultivate an attitude of caring for the environment are less than optimal. This is showed by the learning process only listed in the textbook. The material in the textbooks used rarely takes this into account as a result students with all environmental problems are forced to only study theoretically. Learning is only theoretical in the classroom, students are not invited to see the state of the environment or reality is around, and are not involved directly to solve problems relating to the environment based on the reality is around students.

To overcome this problem, the researcher will apply the Problem Based Learning model, especially in the human and environmental sub-themes, an effort to foster awareness of the benefits of environmental preservation. Through this learning model students construct knowledge independently so that these activities will make students feel concerned about the environment that can ultimately form positive attitudes and behaviors towards the environment.

Problem Based Learning is one of the learning models using problems for learning, before students learn a thing, students are required to identify a problem, whether faced by real or case study. The problem posed is such that students find the learning needs needed to solve the problem [2]. Problem Based Learning also provides students with provisions on how to learn to experience problems and solve them so that students can truly get authentic knowledge and experience.

Problem Based Learning has steps in the learning process that must be well understood. It is intended that the learning model is directed and can achieve the expected goals in the learning process. According to [3], the syntax of the Problem based learning model are: (1) phase I: problem orientation; (2) phase II: organizing students to learn; (3) phase III: independent and group investigations; (4) phase IV: developing and presenting artifacts and exhibits; and (5) phase V: analyzing and testing the problem-solving process. The five phases above are expected to help achieve the learning objectives of the Natural Sciences content set in Permendikbud No. 65 of 2013[4].

Attitude is a feeling or a way to react to a stimulus. According to the view of Gestalt learning theory, the emergence of attitudes and behavior occurs because of the interaction of individuals with the environment and 
prioritizes aspects of understanding (Insight). Meanwhile, according to Behavioristic learning theory, attitude change results from the learning process [5]. Some cognitive psychologists also add that attitudes or behaviors are often based on the extent of their knowledge of attitudes they want to change, besides reward and punish [6]. Based on these learning theories it can be concluded that changes in attitudes and behavior can occur for an understanding of something, where understanding is got from a series of learning processes.

The attitude of caring for the environment is a feeling that has someone to improve and manage the environment properly and beneficially, so they can enjoy continuously without damaging the situation, take part in protecting and preserving the environment, these students will become leaders and make policies in maintaining and preserving environment [7], [8].

Indicators of environmental attitudes of elementary school students have the following abilities, 1) identify problems that occur in the surrounding environment, 2) clean up the school environment, 3) throw garbage into the trash, 4) dare to reprimand friends who throw litter, 5 ) able to invite friends to always maintain the school environment, 6) maintain existing plants in school, 7) able to classify organic and inorganic waste, and 8) able to provide solutions to problems that occur.

Based on the gaps in, the researchers planned the problem as follows, a) How to apply the Problem Based Learning model to grade $\mathrm{V}$ students of primary schools, b) How to increase the attitude of caring for the environment after applying the Problem Based Learning model?

The purpose of this study is, a) To find out the application of the Problem Based Learning model for fifth grade elementary schools?, b) To find out the increase in the attitude of caring for the environment after applying the Model Problem Based Learning in elementary school.

\section{RESEARCH METHODS}

The research to be carried out his classroom action research. Classroom action research is an examination of activities that are deliberately raised and occur in a class. This class action research has the aim to improve or improve the quality (quality) of learning in the classroom through a certain action (treatment) in one or several cycles as needed [9]. Class action research stage 1) planning, 2) action, 3) observation, and 4) reflection, Kemmis and Mc Taggart [10].

The classroom action research model is spiral and continuous if the target results of the actions taken have not been achieved then proceed with the next cycle. The class action research design is Kemmis and Taggart's model as shown at figure 1.

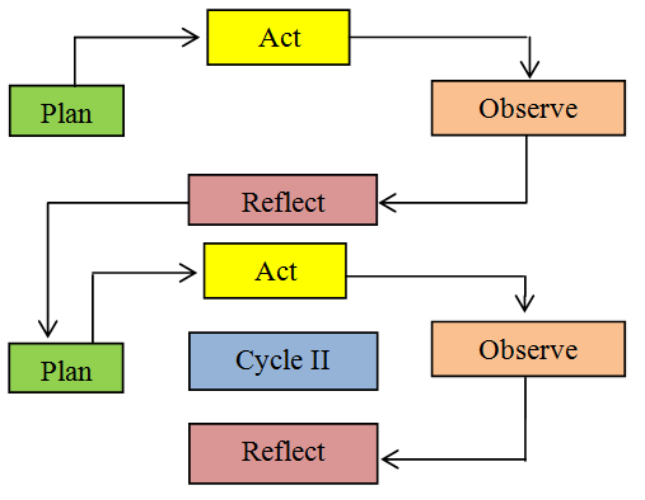

Fig. 1. Kemmis and mc taggart design classroom action research

The object of this research is the attitude of caring for the environment, while the subjects of the study are the fifthgrade students of SD Inpres Seringgu in the 2019/2020 school year with 15 men and 15 women. The research data collection technique comprised observing environmental attitudes which were compiled on 8 indicators and field notes. For the analysis of environmental attitudes used a formula adapted from Campbell, as follows $\mathrm{A}=\Sigma \mathrm{S} / \mathrm{N} \times 100$ (1) where $\mathrm{A}=$ attitude to care about the environment, $\Sigma \mathrm{S}=$ the total number of respondents score, and $\mathrm{N}=$ maximum score

Interpretation of environmental concern attitudes is based on table 1.

TABLE I. VIRONMENTAL CONCERN ATTITUDE CATEGORIES

\begin{tabular}{|c|c|}
\hline Score & Categories \\
\hline$<60$ & Less \\
\hline $60-70$ & Enough \\
\hline $71-80$ & Well \\
\hline$>80$ & Very good \\
\hline
\end{tabular}

\section{RESULTS AND DICUSSIONS}

\section{A. Results}

After conducting research and data processing, an analysis of attitudes per indicator is then carried out, and a score got on the scale of the environmental care category as shown in figure 2 below:

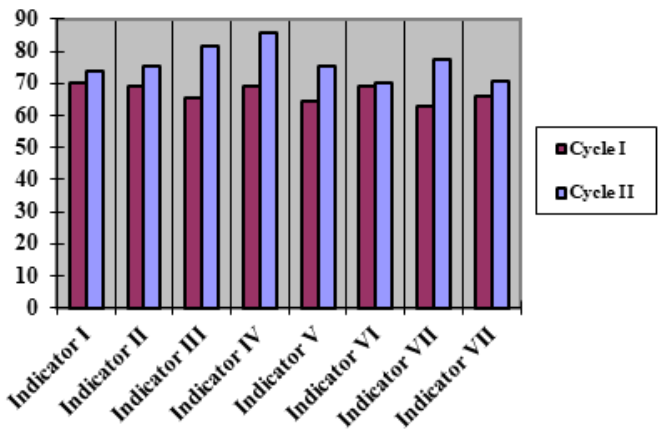

Fig. 2. The comparison of environmental concern attitude

Based on the figure 2, comparison of the achievement of indicators for each cycle shows that the first cycle observed environmental attitudes observed: (1) identify the problems 
that occur in the surrounding environment that gets the percentage of $70,25 \%$ (well), the second cycle got by 73,86 $\%$ (well), 2) cleaning the cycle I school environment by $69,21 \%$ (enough), and the condition of the end of the second cycle results a percentage of $75,50 \%$ (well), 3) throwing garbage into the trash in the first cycle to get an adequate assessment (enough) that is equal to $65,45 \%$, then in cycle II $81,45 \%$ (very good), 4) dare to reprimand friends who littering in cycle I indicator four is $69,08 \%$ (enough), and cycle II is $85,65 \%$ (very good), 5) able to invite friends to always protect the environment in the first cycle that received sufficient assessment (enough) as much as $64,35 \%$, while the second cycle yielded a percentage of $75,51 \%$ (well), 6) Nurturing existing plants in schools in the cycle of $69,30 \%$ (enough) and cycle II of $70,40 \%$ (well), 7) could manage the grouping of organic and inorganic waste in cycle I was $62,75 \%$ (enough) and cycle II was $77,63 \%$ (well), 8) able to provide solutions to problems that occurred in cycle I amounted to $65,80 \%$ (enough) and conditions the end of the second cycle $70,65 \%$ (well). In cycle II, all indicators have experienced a different increase each indicator and the highest increase is the indicator of throwing garbage into the trash in cycle II. The achievements of the average attitude of environmental care from cycle I to cycle II as shown in figure 3:

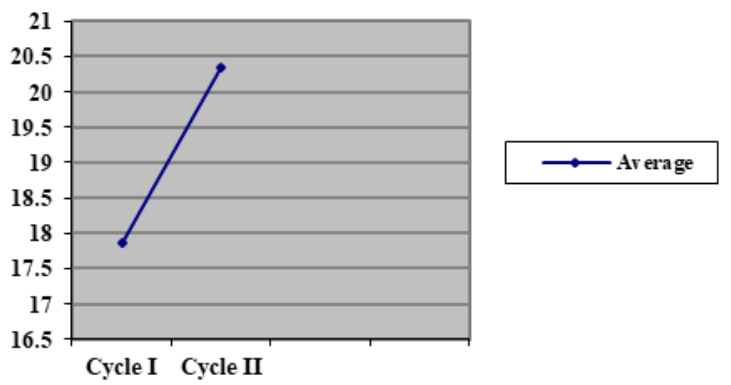

Fig. 3. The average performance indicator of environment concern attitudes

Based on Figure 3, seen an increase in the average achievement of students' environmental care attitude from the initial conditions to the end of the second cycle. The average achievement of the class in the first cycle was 17,87 and the average achievement of the second cycle was 20,34. So that from cycle I to cycle II the average attitudes of caring for the environment increased by applying the Problem Based Learning model.

\section{B. Discussions}

The purpose of classroom action research is to improve the attitude of caring for the environment by using the Problem Based Learning model can be said to be less than the maximum in the first cycle because some indicators are still sufficient categories as in the indicator 2) clean up the school environment by getting sufficient assessment, 3) throwing garbage into the trash can get appraisal is sufficient or there are no students classified as good in throwing garbage into the trash, 4) dare to reprimand friends who glittering with enough categories, 5) able to invite friends to always protect the environment with sufficient assessment, 6) maintain plants are in schools with adequate assessment, 7) able to classify organic and inorganic waste with adequate assessment, and 8) able to provide solutions to problems that occur by getting sufficient assessment.

Of the several deficiencies in the first cycle, researchers conducted reflection and discussion with the class teacher to plan an action to improve cycle I. learning in cycle II had made some improvements from reflection cycle I. In cycle II, the teacher carried out learning to the maximum. Teachers carry out learning by using the syntax of problem based learning models proposed by [3]. Previously there was still communication in the teacher using the syntax of learning, but in cycle II the teacher had used the syntax to the maximum. In line with the results of research conducted by [11] that the learning outcomes of students taught by the Problem based Learning model are better than students taught by the conventional model.

In addition, educators have also provided maximum group discussion help. Through monitoring of discussion groups. Educators have given examples and are always reminded about separating and disposing of plastic and nonplastic waste properly in its place. In addition, educators do not forget to remind students to protect the grass and plants from being trampled. Students also protected the environment around the school, which was shown by cooperation in cleaning the school environment and conducting campaigns to protect the environment of other classmates. This is in line with the Gestalt learning theory, the emergence of attitudes and behavior occurs because of the interaction of individuals with the environment and prioritizes aspects of understanding (insight).

According to [7], [8] that the attitude of caring for the environment is a feeling that has someone to improve and manage the environment properly and beneficially, so that they can enjoy continuously without damaging the situation, contribute to protecting and preserving the environment, these students will later become leaders and make policies in maintaining and preserving the environment. This is in line with research conducted by [12] that attitudes can actually change and develop because of the results of the learning process in the presence of new experiences that experienced by individuals.

Overall the percentage of achievement indicators in the second cycle has increased compared to the first cycle because in the second cycle students were trained with environmental care indicators very well in the learning process using the Problem Based Learning model. The results got from the graph 1 . for the statement of attitude per indicator, the highest score of attainment results got from the attitude indicator to dare to reprimand friends who littering by $85,65 \%$ (very good), attitude indicators that are categorized as good are indicators capable of grouping organic waste and inorganic amounted to $77,63 \%$ (well) this means that students already have an attitude of increasing environmental care.

Thus, Problem Based Learning can create a conducive, active, creative and fun classroom environment, and shape students personalities, so as to produce an understanding of students environmental care attitudes that are low to be improved by applying the Problem Based Learning model.

\section{CONCLUSION}

From the research that has been done, it can be concluded that: 1) the implementation of learning to accord to the 
syntax of the Problem Based Learning model, 2) the attitude of caring for the environment of class $\mathrm{V}$ students has increased by applying the Problem Based Learning model, 3) The category of the attitude of caring for the environment of students is in a good category of 77,63\% is in the seventh indicator able to classify organic and inorganic waste, while the very good category is in the fourth indicator that is dared to reprimand friends who glittering with an assessment of $85,65 \%$.

\section{ACKNOWLEDGMENT}

Thanks to Universitas Musamus and SD Inpres Seringgu.

\section{REFERENCES}

[1] Rahayu, D.P Lieung, K. W. and Fredy "The use of reading material based contextual approach to improve environmental concern attitude of elementary school students," in IOP Conf. Series: Earth and Environmental Science 343 (2019) 012225, 2019.

[2] A. Muhson, "Peningkatan Minat Belajar dan Pemahaman Mahasiswa Melalui Penerapan Problem Based," J. Kependidikan, vol. XXXIX, Nom, 2009.

[3] R. I. Arends, Learning to Teach ninth edition. New York: McGraw-Hill, 2012.

[4] Kemendikbud, Peraturan Menteri Pendidikan dan Kebudayaan Republik Indonesia Nomor 65 Tahun 2013 tentang Standar Proses Pendidikan Dasar dan Menengah. 2013.

[5] S. Suryabrata, Psikologi Pendidikan. Jakarta: PT Raja Grafindo Persada, 2006.

[6] Watsy Soemanto, Psikologi Pendidikan. Jakarta: PT Rineka Cipta, 2006.

[7] Kemendiknas, Buku Induk Pembangunan Karakter. Jakarta, 2010.

[8] L. L. Wray, F. C. A, and D. W. Osgood, "Examining Trends in Adolescent Environmental Attitudes, Beliefs, and Behaviors Across Three Decades," Environ. Behav., vol. Volume 42, 2010.

[9] Z. Aqib, Pendidikan Karakter di Sekolah. Bandung: Yrama Widya, 2012.

[10] S. Arikunto, Metodologi Penelitian Suatu Pendekatan. Jakarta: PT Rineka Cipta, 2002.

[11] U. Yampap and R. Purwanty, "Improvement of Student Learning Outcomes through Problem Based Learning Model Class IV Basic School," J. Basic Appl. Sci. Res., vol. J. Basic., no. ISSN 2090-4304, 2019.

[12] U. Yampap, R. Bay, and K. Lieung, "Improving Fourth Grade Students' Science Larning Achivement Using Process Skill Approach At Inpres Mangga Dua Elementary School of Merauke," in In International Conference on Social Science 2019 (ICSS 2019)., 2019. 